\title{
PENINGKATAN MODEL GROUP INVESTIGATION PADA PEMBELAJARAN MENULIS TEKS LAPORAN HASIL OBSERVASI SISWA KELAS X TKJ SMK SWASTA BUDI SETIA SUNGGAL TAHUN PELAJARAN 2018/2019
}

\author{
Rahmadini Syahfitri ${ }^{1}$, Annisa ${ }^{2}$, Dani Sukma Agus Setiawan ${ }^{3}$ \\ Universitas Prima Indonesia ${ }^{1}$, Universitas Prima Indonesia ${ }^{2}$, Universitas Prima Indonesia ${ }^{3}$ \\ Pos-el: rahmadinisyahfitri01@gmail.com¹, rindi.nisa48@gmail.com², \\ danisukmaagussetiawan@unprimdn.ac.id ${ }^{3}$
}

\begin{abstract}
ABSTRAK
Penelitian ini bertujuan untuk meningkatkan keterampilan menulis teks laporan hasil observasi siswa kelas X TKJ SMK Swasta Budi Setia Sunggal melalui model group investigation. Penggunaan model group investigation diharapkan mampu mempermudah siswa dalam memahami materi dan mampu menulis teks laporan hasil observasi agar keterampilan menulis meningkat. Melalui model group investigation, peningkatan dapat dilihat secara proses maupun produk. Penelitian ini merupakan penelitian tindakan kelas (PTK). Penelitian ini dilaksanakan di SMK Swasta Budi Setia Sunggal. Subjek penelitian adalah kelas X TKJ yang berjumlah 28 siswa. Hal ini dilihat dari peningkata skor rata-rata setelah diberi siklus I dengan rata-rata 74,11 dan pada akhirnya siklus II skor rata-rata menjadi 82,01. Peningkatan skor ratarata siswa mulai siklus I hingga siklus II adalah 7,9. Secara keseluruhan pada akhir siklus II semua berdasarkan hasil penelitian tersebut, dapat disimpulkan bahwa penggunaan model group investigation berhasil dan mampu meningkatkan keterampilan menulis teks laporan hasil observasi siswa kelas X TKJ SMK Swasta Budi Setia.
\end{abstract}

Kata Kunci: Group Investigation, Teks Laporan Hasil Observasi, Menulis.

\section{ABSTRACT}

This study aims to improve the report writing skills of the observation results of class $X$ TKJ SMK Setia Sunggal through a group investigation model. The use of the group investigation model is expected to facilitate students in understanding the material and be able to write the text of the observation report so that writing skills increase. Through the group investigation model, improvements can be seen in both process and product. This research is a classroom action research (CAR). This research was conducted at Budi Setia Sunggal Private Vocational School. The research subjects were class X TKJ which amounted to 28 students. This is seen from the increase in the average score after being given the first cycle with an average of 74.11 and in the end the second cycle scores on average to 82.01. The increase in the average score of students from cycle I to cycle II is 7.9. Overall at the end of the second cycle all based on the results of the study, it can be concluded that the use of the investigation group model was successful and was able to improve the writing skills of the report report text of class X TKJ SMK Swasta Budi Setia.

Keywords: Group Investigation, Text Report on Observation, Writing. 


\section{PENDAHULUAN}

Model pembelajaran adalah seluruh rangkaian atau kerangka materi pembelajaran yang meliputi segala aspek prosedur yang sistematis dalam mengorganisasikan pengalaman belajar untuk mencapai tujuan belajar tertentu, sebelum dan sesudah pembelajaran yang dilakukan oleh guru serta segala fasilitas yang terkait yang digunakan secara langsung maupun tidak langsung dalam proses belajar mengajar.

Dalam menyampaikan materi pembelajaran teks laporan hasil observasi dibutuhkan model pembelajaran agar proses belajar mengajar dapat berjalan dengan baik. Model pembelajaran harus sesuai dengan materi pembelajaran agar proses dalam belajar mengajar berlangsung dengan baik dan peserta didik dapat memahami materi teks laporan hasil observasi yang disampaikan oleh guru.

Masih banyak peserta didik yang kurang memahami materi teks laporan hasil observasi yang disampaikan oleh guru dikarenakan model pembelajaran yang kurang sesuai dengan materi pembelajaran teks laporan hasil observasi. Oleh karena itu model pembelajaran harus sesuai dengan mate pembelajaran agar siswa dapat memahami materi pembelajaran teks laporan hasil observasi yang disampaikan oleh guru.

Menulis merupakan suatu kegiatan yang mengungkapkan gagasan pikiran, perasaan beserta pengalaman melalui sebuah tulisan yang bertujuan untuk memberikan informasi kepada orang lain agar orang lain dapat mengetahui isi informasi tersebut.

Teks laporan hasil observasi adalah sebuah teks laporan yang bertujuan memaparkan informasi sesuai dengan fakta mengenai suatu objek tertentu. Teks laporan hasil observasi ini memaparkan laporan berdasarkan dengan apa yang ada tidak berdasarkan dengan hasil imajinasi atau karangan.
Melihat banyaknya manfaat yang akan diperoleh dalam pembelajaran menulis, seharusnya kegiatan menulis ini menjadi kegiatan yang diminati oleh banyak siswa. Namun kondisi kenyataannya masih banyak siswa yang beranggapan bahwa menulis adalah kegiatan yang masih sulit bagi siswa. Masih banyak siswa yang malas dan tidak bersemangat untuk mengikuti kegiatan menulis.

Kondisi tersebut disebabkan oleh rendahnya minat menulis siswa, penguasaan kosa kata dan penggunaan model pembelajaran yang kurang tepat. Khususnya dalam pembelajaran menulis teks laporan hasil observasi masih banyak siswa yang kurang minat untuk mengikuti pembelajaran menulis teks laporan hasil observasi.

Semua itu terlihat saat siswa mengikuti pembelajaran materi teks laporan hasil observasi, siswa di dalam kelas ada yang mengobrol, ada yang tidur, ada yang bermain handphone dan ada juga yang berulang-ulang kali iziı permisi ke kamar mandi. Mungkin bag1 sebagian siswa materi teks hasil observasi adalah materi yang sangat membosankan sehingga mereka malas dan tidak minat untuk mengikuti pembelajaran teks hasil laporan observasi.

Dari penjelasan tersebut, model pembelajaran group investigation merupakan salah satu model yang sesuai untuk digunakan dalam materi pembelajaran menulis teks laporan hasil observasi. Karena model ini sangat memiliki dampak yang positif bagi siswa, yaitu dapat meningkatkan kemampuan belajar siswa, dapat meningkatkan semangat belajar siswa, dapat meningkatkan kerjasama antar siswa dan interaksi antar siswa tanpa memandang latar belakang siswa lainnya, model ini juga mendorong siswa agar tetap aktif dalam melakukan kegiatan pembelajaran, meningkatkan kepercayaan diri pada siswa, 
meningkatkan kekreatifan siswa, siswa dapat belajar lebih pendapat menghargai orang lain, meningkatkan kepeduliian siswa kepada orang lain, dan siswa terlatih untuk lebih bertanggung jawab dengan tugas yang diberikan.

Dengan diterapkan model pembelajaran group investigation dalam hubungannya dengan menulis teks laporan hasil observasi dapat membantu nalar peserta didik untuk menjelaskan apa yang dilihat di sekitar lingkungannya sehari-hari, memperhatikannya, pengalaman-pengalaman yang dimilikinya, dan akhirnya dapat mengemukakan ide melalui fakta-fakta kemudian ditulis lewat kalimat yang dikembangkan menjadi teks laporan hasil observasi. Dengan demikian model pembelajaran group investigation sangat membantu guru untuk mengajar dan mengaitkan antara yang diajarkan guru dengan situasi dunia.

Identifikasi masalah dalam penelitian ini berupa kemampuan menulis teks laporan hasil observasi masih rendah, penggunaan metode atau model yang kurang tepat, upaya meningkatkan kemampuan menulis teks laporan hasil observasi dengan model pembelajaran group investigation.

\section{METODE PENELITIAN}

Penelitian ini menggunakan metode penelitian tindakan kelas (PTK). Penelitian ini merupakan salah satu strategi pemecahan masalah yang memanfaatkan tindakan nyata dan proses pengembangan kemmapuan dengan memnafaatkan interaksi, partisipasi, dan kolaborasi. Penelitian ini akan menciptakan kolaborasi dan partisipasi antara penulis dan guru kelas. Penulis terlihat langsung dalam proses penelitian sejak awal sampai dengan hasil penelitian berupa laporan. Dengan demikian, sejak perencanaan penelitian penulis senantiasa terlibat. Selanjutnya penulis memantau, mencatat, dan mengumpulkan data, kemudian menganalisis data serta berakhir dengan melaporkan hasil penelitiannya. Penelitian ini akan menciptakan kolaborasi atau partsipasi antara penulis dengan guru kelas. Dalam penelitian ini metode yang digunakan adalah metode kualitatif. Metode kualitatif digunakan untuk mendapatkan data yang mendalam, suatu data yang mengandung makna. Makna adalah data yang sebenarnya, data yang pasti yang merupakan suatu nilai di balik data yang tampak.

Penelitian kualitatif bertujuan memperoleh gambaran seutuhnya mengenai suatu hal menurut pandangan manusia yang diteliti. Penelitian kualitatif berhubungan dengan ide, persepsi, pendapat atau kepercayaan orang yang diteliti dan kesemuanya tidak dapat diukur dengan angka.

\section{HASIL DAN PEMBAHASAN}

Penelitian ini merupakan penelitian tindakan kelas yang menggunakan model group investigation dalam menulis teks laporan hasil observasi. Pada bab ini, akan disajikan hasil penelitian yang sesuai dengan kegiatan yang telah dilaksanakan. Hasil yang diperoleh dalam penelitian tindakan kelas tersebut akan diuraikan lebih lanjut di bawah ini.

Keberhasilan produk dapat dilihat dari hasil menulis teks laporan hasil observasi siswa pada tindakan siklus I mendapat nilai rata-rata 74,11. Siswa yang tuntas dalam penulisan teks laporan hasil observasi ada 16 siswa, sedangkan yang tidak tuntas ada 12 siswa. Jumlah keseluruhan siswa kelas X SMK Budi Setia adalah 28 siswa.

Pada siklus II diketahui skor ratarata siswa pada akhir tindakan adalah 82,01 , sedangkan rata-rata keteampilan menulis teks laporan hasil observasi siswa siklus I diberi tindakan adalah sebesar 74,11. Hal ini menunjukkan bahwa peningkatan yang terjadi pada siklus II cukup signifikan yaitu sebesar 
7,9. Pada siklus II, peningkatan terjadi pada setiap aspek menulis teks laporan hasil observasi.

Skor rata-rata awal siswa pada siklus I sebesar 74,11. Pada siklus II rata-rata skor menunjukkan peningkatan yang lebih signifikan yaitu 82,01.

Pada siklus I dapat disimpulkan bahwa keterampilan menulis teks laporan hasil observasi siswa kelas $\mathrm{X}$ SMK SWASTA BUDI SETIA SUNGGAL TAHUN PELAJARAN 2018/2019 tersebut memperoleh 9 $(32,43 \%)$ siswa yang berantusias. 7 (25\%) Siswa yang tidak memperhatikan penjelasan. sedangkan 12 Siswa $(42,57 \%)$ yang tidak menunjukkan sikap yang berbeda-beda.

Pada siklus II terdapat 26 $(92,575)$ Siswa yang berantusias. Sedangkan siswa yang tidak berantusias sudah berkurang yaitu $2(71,43 \%)$ siswa. Pada siklus II keaktifan siswa proses pembelajaran berlangsung sudah meningkat dibandingkan siklus I, yaitu $26(92,57 \%)$ siswa.

Siswa yang tidak aktif sudah berkurang yaitu $2(71,43 \%)$. Siswa yang memberikan respon atau sikap siswa dalam proses belajar berlangsung sekitar $24(85,14 \%)$. Siswa yang kurang respon sebanyak $2(71,43 \%)$.

\section{SIMPULAN}

Berdasarkan hasil penelitian yang telah dijelaskan pada bab sebelumnya, dapat disimpulkan bahwa model group investigation dapat digunakan untuk meningkatkan keterampilan menulis teks laporan hasil observasi siswa kelas X SMK Budi Setia.

1. Proses yang terjadi setelah dikenai tindakan meliputi peningkatan proses dan produk. Peningkatan dari hal proses dapat dilihat dari pelaksanaan pembelajaran yang berlangsung dengan baik. Dapat dikatakan baik karena, siswa merasa nyaman dan memahami materi yang disampaikan. Peningkatan proses juga meliputi keseluruhan perilaku peserta didik selama proses pembelajaran. Peserta didik lebih memperhatikan dan merespon dengan antusias terhadap penjelasan peneliti.

Selama proses menulis teks laporan hasil observasi berlangsung, peserta didik ikut berpartisipasi secara aktif dalam kegiatan berinteraksi atau kerjasama dengan peserta didik lainnya. Pesrta didik merespon positif terhadap model group investigation yang digunakan. Selain itu, terjadi Tanya jawab yang baik antara peneliti dan peserta didik. Hal ini menjadikan pembelajaran menulis teks laporan hasil observasi lebih kondusif dan lebih menarik.

2. Hasil ditunjukkan dengan skor ratarata dari siklus I hingga siklus II. Mulai dari skor rata-rata 74,11 menjadi 82,01. Peningkatan skor rata-rata meningkat sebesar. Peningkatan produk dapat dilihat dari skor rata-rata kelas yang diperoleh dari tahap siklus I sampai siklus II. Pada tahap siklus I diperoleh skor rata-rata sebesar 74,11. Selanjutnya, terjadi peningkatan skor rata-rata menulis teks laporan hasil observasi pada siklus II menjadi 82,01. Pada siklus I yang tuntas 16 siswa dengan keberhasilan $0,57 \%$ dan yang tidak tuntas 12 siswa dengan keberhasilan $0,42 \%$. Pada siklus II terjadi peningkatan yang tuntas 28 siswa dengan keberhasilan $100 \%$. Siklus I indikator keberhasilan siswa belum tercapai masih di bawah $75 \%$ yaitu $0,42 \%$, tetapi pada siklus II sudah di atas indikator keberhasilan yaitu $100 \%$. Hal tersebut menunjukkan adanya peningkatan 7,9 dari tahap siklus I sampai siklus II. Hasil dari tindakan yang dilakukan hingga siklus II telah memenuhi indikator keberhasilan yaitu $75 \%$ siswa mendapatkan skor lebih dari atau sama dengan dari skor maksimal 100 setelah diberikan tindakan.

3. Adanya peningkatan pada siklus II semua aspek dan kriteria menulis teks laporan hasil observasi mengalami penibgkatan yang signifikan. Pada siklus 
II terjadi peningkatan yang tuntas siswa 29 siswa dengan keberhasilan 100\% dan yang tidak tuntas 0 siswa dengan keberhasilan 0\%. Dari haisl penelitian tersebut terbukti bahwa penggunaan model group investigation dinilai berhasil dan dapat meningkatkan keterampilan menulis teks laporan hasil observasi siswa kelas X SMK Budi Setia.

\section{DAFTAR PUSTAKA}

Arikunto. S. 2017. Prosedur Penelitian. Jakarta: Rineka Cipta.

Arikunto. S. dkk. 2017. Penelitian Tindakan Kelas. Jakarta: PT Bumi Aksara.

Dalman. H. 2015. Keterampilan Menulis. Jakarta: Raja Grafindo Persada.

Hidayah. N. 2013. Panduan Praktis Penyusunan dan Pelaporan PTK (Penelitian Tindakan Kelas). Jakarta: Prestasi Pustaka Karya.

Istarani. 2017. 58 Model Pembelajaran Inovatif. Medan: Media Persada.

Kosasih. E. 2013. Jenis-Jenis Teks. Bandung: Yrama Widya.

Kosasih. E. 2013. Cerdas Berbahasa Indonesia untuk SMA/MA Kelas $X$. Jakarta: Erlangga.

Kosasih. E. 2013. Cerdas Berbahasa Indonesia untuk SMA/MA Kelas $X$ Kelompok Wajib. Jakarta: Erlangga.

Kurniasih. I. 2015. Ragam Pengembangan Model Pembelajaran. Kata Pena.

Shoimin. A. 2017. 68 Model Pembelajaran Inovatif dalam Kurikulum 2013.Sambilegi: ArRuzz Media.

Sulistyowati. Trisni. Dkk. 2014. Bahasa Indonesia Kebanggaan Bangsaku untuk SMA dan MA Kelompok Mata Pelajaran Wajib. Surakarta: Platinum

Tarigan. G. H. 2013. Menulis Sebagai suatu Keterampilan Berbahasa. Bandung: Angkasa Bandung.
Wijaya Candra H. dan Syahrum 2017.

Penelitian Tindakan Kelas.

Bandung: Cita Pustaka Media Perintis.

Yustinah. 2016. Produktif Berbahasa Indonesia untuk SMK/MA Kelas $X$. Kudus: Erlangga.

Zainurrahman. 2013. Menulis Dari Teori Hingga Praktik. Bandung:

Alfabeta 